\title{
Communication and the Decision Making Process among Couples with HIV/AIDS in Bulawayo, Zimbabwe
}

\author{
V. Ndlovu \\ Department of Development Studies, Lupane State University, 44 H. Chitepo Street, Bulawayo, Zimbabwe \\ Correspondence should be addressed to V. Ndlovu; veziestha@yahoo.co.uk
}

Received 12 December 2013; Accepted 13 February 2014; Published 17 March 2014

Academic Editors: K. Falasca, V. C. Marconi, D. Nardelli, F. Uribe-Salas, and P. Weatherburn

Copyright ( 2014 V. Ndlovu. This is an open access article distributed under the Creative Commons Attribution License, which permits unrestricted use, distribution, and reproduction in any medium, provided the original work is properly cited.

\begin{abstract}
The study explores how HIV-positive couples negotiate and make reproductive and sexually related decisions. The broader aim of the paper is to understand how men and women with HIV make decisions about contraception and reproduction and what those decisions indicate about the realities of HIV-positive relationships. In line with the study's aim to explore meanings related to the decision making process, a qualitative research approach was adopted. In-depth interviews were conducted with 15 couples in which at least one of them was HIV-positive. A critical interpretive analysis of the data was adopted in order to gain insight into decision making among the HIV-positive couples. The results indicate that decisions made were usually a result of negotiation and compromise between partners. However, women's fertility and sexual preferences were found to be a major factor in determining the outcome of the decision making process. Couples who intended to have a child were found to be active decision makers while those who only desired or did not desire to have a child were mainly passive decision makers. The study concludes that women exercise significant power over contraceptive and reproductive decisions among both active and passive decision makers.
\end{abstract}

\section{Introduction}

Men and women of reproductive age are the largest group infected with HIV in Zimbabwe. Over 10\% of the reported HIV/AIDS cases in Zimbabwe are among people aged 15 and above [1]. This incidentally is the age group in which most partnerships or marriages occur. The high prevalence of HIV within the reproductive population means that a greater number of couples have to grapple with the ultimate reproductive decision - to have or not to have a child. The availability and accessibility of ART have made this issue more pertinent as more infected people are now living longer and healthier. It is estimated that around $86 \%$ of people who need ARVs in Zimbabwe are currently covered [2].

Decision making in whatever context is a complex issue and gender is generally regarded as one of the power sources in reproductive decision making $(4,5)$. As sociologists have argued, socioculturally constructed gender norms and values ascribe differential powers and responsibilities to both men and women $(4,5)$. In most African societies men are generally regarded as formidable barriers to women's decision making about reproduction and contraceptive use $(4,5,6)$. It is generally accepted as conventional wisdom that women have no control or power over the means of reproduction in Zimbabwe and other males dominated societies. Male dominance is seen as spread over both the public and private domain making it virtually impossible for a woman to move, act, or think freely $(7,8,14)$. It seems therefore that sociocultural gender norms give more power and control over family matters to men, thus enabling them to dominate the process of reproductive decision making.

Given this scenario, this study aims to explore how HIV-positive couples negotiate and make reproductive and sexually related decisions. The paper will pay particular attention to the influence of women on reproductive decision making among HIV-positive couples. The broader aim of the paper is to understand how men and women with HIV make decisions about contraception and reproduction, how 
those decisions are influenced by broader social patterns and gender power dynamics, and what those decisions indicate about the realities of HIV-positive relationships.

\section{Methods}

Since the purpose of the study was to explore an issue that exists within a personal and subjective level, a qualitative interpretive approach was adopted. Such an approach allows the researcher to be open to the attitudes and values of the participants and to interpret their views in a way that takes cognizance of the environment in which they exist. The researcher conducted in-depth interviews with HIVpositive heterosexual couples in Bulawayo, Zimbabwe, in 2010. The sample consisted of 13 seroconcordant couples and 2 serodiscordant couples. The age of the sample ranged from 24 to 43 with the median age being 34 . Most of the people interviewed had some secondary education with 6 having completed only primary education (grade 7). The study was conducted in an urban setting, in the high density suburbs of Bulawayo, where the respondents lived. In terms of socio-cultural status, the respondents fell mainly in the low income bracket with their income ranging between US $\$ 50$ and US $\$ 100$ a month at the time the research was conducted. The couples were interviewed separately about their sexual and reproductive lives, decision making, and their fertility intentions both before and after diagnosis. Of the fifteen couples, only two couples and six other individuals expressed an intention to have a child. It is notable however that none of these couples or individuals has had a child or pregnancy after diagnosis.

The main characteristics of the study sample are summarised in Table 1.

The interviews were conducted in places chosen by the couples. Couples were eligible to participate if both or one of them was HIV-positive, if they were in an intimate relationship, if they had disclosed their HIV-positive status to each other, and if they were confronting, will be confronting or had confronted reproductive decision making, and were able to complete the interview in Ndebele, Shona, or English.

Two strategies were used to recruit respondents. One was to recruit willing participants from support groups and opportunistic infections clinics through distributing recruitment flyers and the other was snowball sampling. Permission to distribute flyers and interact with HIV-positive people was sought and granted by the relevant authorities in opportunistic infections clinics and in support groups. Snowballing was used in this study as it offers better chances of accessing hard to reach and stigmatised groups like HIVpositive people. Usually in a "closed group", a link exists between the initial sample and others in the same target population, allowing a series of referrals to be made within a circle of acquaintance $[3,4]$. The initial couples who came forward in response to the recruitment flyer were asked after the completion of the interviews if they knew another couple or couples that would be willing to participate in the study. To avoid violating the privacy of individuals, the referring couple was asked to contact the prospective couple using the researchers' resources and inform them of the referral. In this way, the researcher moved from one couple to the next and managed to access most of the respondents in this study that would otherwise have been missed.

Ethical approval for the study was obtained from the Human Research Ethics Committee (nonmedical) of the University of the Witwatersrand (Protocol H091111, February 2,2010 ). Informed consent was obtained from every participant before the interview was conducted and consent forms were signed. Taped interviews were transcribed in the original language and then translated into English. Transcribed interviews were then content analysed and coded according to patterns and themes concerning reproduction among HIV-positive people. A critical interpretive analysis of the themes was then done to determine the nature and process of decision making among HIV-positive couples.

\section{Results}

The results of the study indicate that though men play a role in reproductive decision making, they do not seem to dominate the decision making process among couples studied. HIVpositive women seemed to have significant influence and to be more assertive in determining the nature of their sexual and reproductive engagement with their partners. Among all the couples interviewed, there was no case where decisions pertaining to reproductive issues after diagnosis can be said to have been dominated by men. The results also indicated that the level of education and economic status did not have a significant impact on the reproductive decision making process.

3.1. Communication on Reproductive and Sexually Related Issues among Couples with HIV/AIDS. Communication regarding reproductive and sexual issues was found to be lacking among some of the couples interviewed. The position of the other partner was either assumed or taken for granted. The couples usually assumed that their positions on sexual and reproductive issues were in tandem and hence did not merit any discussion. While decisions had been made at the individual level, they had not been communicated or discussed at the couple level. For example, in couple 15, both partners expressed a strong desire to have a child but they had not communicated this to each. Questioned on whether they had discussed their desire for a child, C15F had this to say,

"no we have not talked about it because we told ourselves that since we are positive we should no longer have a child. But the truth is that we both want a child. That is where the problem is."

Her partner said, "I do want to have a child but because of this (HIV) I do not think I can. I however have not discussed this with my wife."

Couple 7 also assumed that since they were HIV-positive, the sensible thing was not to have children without discussing this with each other. C7F said, "we have not discussed it; we still need to sit down and talk about it because you cannot make a child alone...” 
TABLe 1

\begin{tabular}{|c|c|c|c|c|c|c|c|c|c|}
\hline $\begin{array}{l}\text { Couple } \\
\text { identification } \\
\text { number }\end{array}$ & Age & $\begin{array}{l}\text { Relationship } \\
\text { status }\end{array}$ & $\begin{array}{l}\text { Number of } \\
\text { children }\end{array}$ & $\begin{array}{c}\text { On ARVs? } \\
\text { Since } \\
\text { when? }\end{array}$ & $\begin{array}{l}\text { Desires to } \\
\text { have } \\
\text { children }\end{array}$ & $\begin{array}{l}\text { Intends to } \\
\text { have } \\
\text { children }\end{array}$ & $\begin{array}{c}\text { Level of } \\
\text { education (years } \\
\text { in school) }\end{array}$ & $\begin{array}{l}\text { HIV status and } \\
\text { year known }\end{array}$ & $\begin{array}{l}\text { Employment } \\
\text { status }\end{array}$ \\
\hline \multicolumn{10}{|l|}{$\mathrm{Cl}$} \\
\hline $\mathrm{F}$ & 36 & $\begin{array}{l}\text { Single; in a } \\
\text { relationship }\end{array}$ & 1 & $\begin{array}{l}\text { Yes: } \\
\text { November } \\
2004\end{array}$ & Yes & No & $\begin{array}{l}\text { Secondary } \\
\text { (11 yrs) }\end{array}$ & $\begin{array}{l}\text { HIV-positive: } \\
\text { May } 2004\end{array}$ & Unemployed \\
\hline M & 33 & $\begin{array}{l}\text { Single; in a } \\
\text { relationship }\end{array}$ & 0 & $\begin{array}{l}\text { Yes: } \\
\text { February } \\
2005\end{array}$ & Yes & Yes & $\begin{array}{l}\text { Secondary } \\
\text { (11 yrs) }\end{array}$ & $\begin{array}{c}\text { HIV-positive } \\
\text { December } 2004\end{array}$ & Self- employed \\
\hline \multicolumn{10}{|l|}{$\mathrm{C} 2$} \\
\hline $\mathrm{F}$ & 32 & Married & 1 & Yes & No & No & $\begin{array}{l}\text { Tertiary } \\
\text { (13 yrs) }\end{array}$ & $\begin{array}{c}\text { HIV-positive } \\
1986\end{array}$ & Peer counsellor \\
\hline M & 35 & Married & 4 & NA & No & No & $\begin{array}{c}\text { Secondary } \\
(9 \mathrm{yrs})\end{array}$ & HIV-negative & Musician \\
\hline \multicolumn{10}{|l|}{$\mathrm{C} 3$} \\
\hline F & 42 & Married & 3 & No & No & No & $\begin{array}{c}\text { Primary } \\
\text { (7 yrs) }\end{array}$ & $\begin{array}{l}\text { HIV-positive } \\
2004\end{array}$ & Unemployed \\
\hline M & 43 & Married & 2 & No & No & No & $\begin{array}{c}\text { Secondary } \\
(11 \mathrm{yrs})\end{array}$ & $\begin{array}{l}\text { HIV-positive: } \\
2002\end{array}$ & Pensioner \\
\hline \multicolumn{10}{|l|}{$\mathrm{C} 4$} \\
\hline $\mathrm{F}$ & 39 & $\begin{array}{l}\text { Widowed; in } \\
\text { a relationship }\end{array}$ & 3 & No & Yes & Yes & $\begin{array}{l}\text { Secondary } \\
\quad(11 \mathrm{yrs})\end{array}$ & $\begin{array}{l}\text { HIV-positive } \\
\text { August } 2004\end{array}$ & Unemployed \\
\hline M & 40 & $\begin{array}{l}\text { Widowed; in } \\
\text { a relationship }\end{array}$ & 3 & No & No & No & $\begin{array}{c}\text { Secondary } \\
(11 \mathrm{yrs})\end{array}$ & $\begin{array}{c}\text { HIV-positive } \\
\text { Sept. } 2004\end{array}$ & Self- employed \\
\hline \multicolumn{10}{|l|}{$\mathrm{C} 5$} \\
\hline $\mathrm{F}$ & 26 & $\begin{array}{l}\text { Single; in a } \\
\text { relationship }\end{array}$ & 0 & Yes & Yes & Yes & $\begin{array}{c}\text { Tertiary (did not } \\
\text { complete degree } \\
\text { studies) }\end{array}$ & $\begin{array}{c}\text { HIV-positive } \\
2003\end{array}$ & Unemployed \\
\hline $\mathrm{M}$ & 36 & Married & 1 & Yes & Yes & Yes & $\begin{array}{c}\text { Secondary } \\
\text { (11 yrs) }\end{array}$ & $\begin{array}{c}\text { HIV-positive } \\
1996 \\
\end{array}$ & Self- employed \\
\hline \multicolumn{10}{|l|}{ C6 } \\
\hline $\mathrm{F}$ & 33 & $\begin{array}{l}\text { Widowed; in } \\
\text { a relationship }\end{array}$ & 4 & $\begin{array}{l}\text { Yes } \\
\text { August } \\
2004\end{array}$ & No & No & $\begin{array}{c}\text { Primary } \\
(7 \text { yrs })\end{array}$ & $\begin{array}{l}\text { HIV-positive } \\
\text { March } 2001\end{array}$ & Self- employed \\
\hline M & 38 & $\begin{array}{l}\text { Widowed; in } \\
\text { a relationship }\end{array}$ & 3 & Yes & No & No & $\begin{array}{c}\text { Secondary } \\
(11 \mathrm{yrs})\end{array}$ & $\begin{array}{c}\text { HIV-positive } \\
2001\end{array}$ & Security guard \\
\hline \multicolumn{10}{|l|}{$\mathrm{C} 7$} \\
\hline $\mathrm{F}$ & 36 & $\begin{array}{l}\text { Widowed; in } \\
\text { a relationship }\end{array}$ & 2 & No & Yes & No & $\begin{array}{l}\text { Secondary } \\
\text { (11 yrs) }\end{array}$ & $\begin{array}{c}\text { HIV-positive } \\
2003\end{array}$ & Unemployed \\
\hline M & 42 & $\begin{array}{l}\text { Widowed; in } \\
\text { a relationship }\end{array}$ & 3 & Yes & Yes & No & $\begin{array}{c}\text { Secondary } \\
(9 \mathrm{yrs})\end{array}$ & $\begin{array}{c}\text { HIV-positive } \\
2001\end{array}$ & Security guard \\
\hline \multicolumn{10}{|l|}{$\mathrm{C} 8$} \\
\hline $\mathrm{F}$ & 30 & Married & 4 & $\begin{array}{c}\text { Yes } \\
2004\end{array}$ & No & No & $\begin{array}{l}\text { Secondary } \\
\text { (11 yrs) }\end{array}$ & $\begin{array}{c}\text { HIV-positive } \\
2002\end{array}$ & Unemployed \\
\hline $\mathrm{M}$ & 36 & Married & 4 & Yes & No & No & $\begin{array}{c}\text { Secondary } \\
\text { (11 yrs) }\end{array}$ & $\begin{array}{c}\text { HIV-positive } \\
2003\end{array}$ & Self- employed \\
\hline \multicolumn{10}{|l|}{ C9 } \\
\hline $\mathrm{F}$ & 28 & $\begin{array}{l}\text { Single; in a } \\
\text { relationship }\end{array}$ & 1 & Yes & Yes & No & $\begin{array}{l}\text { Secondary } \\
\quad(10 \mathrm{yrs})\end{array}$ & $\begin{array}{c}\text { HIV-positive } \\
2000\end{array}$ & Unemployed \\
\hline M & 30 & $\begin{array}{l}\text { Single; in a } \\
\text { relationship }\end{array}$ & 0 & $\mathrm{NA}$ & Yes & Yes & $\begin{array}{c}\text { Secondary } \\
(11 \mathrm{yrs})\end{array}$ & HIV-negative & Factory worker \\
\hline \multicolumn{10}{|l|}{$\mathrm{C} 10$} \\
\hline $\mathrm{F}$ & 33 & Married & 4 & Yes & No & No & $\begin{array}{c}\text { Primary } \\
\text { (7 yrs) }\end{array}$ & $\begin{array}{c}\text { HIV-positive } \\
2001\end{array}$ & $\begin{array}{c}\text { Community } \\
\text { worker }\end{array}$ \\
\hline
\end{tabular}


TABle 1: Continued.

\begin{tabular}{|c|c|c|c|c|c|c|c|c|c|}
\hline $\begin{array}{l}\text { Couple } \\
\text { identification } \\
\text { number }\end{array}$ & Age & $\begin{array}{l}\text { Relationship } \\
\text { status }\end{array}$ & $\begin{array}{l}\text { Number of } \\
\text { children }\end{array}$ & $\begin{array}{l}\text { On ARVs? } \\
\text { Since } \\
\text { when? }\end{array}$ & $\begin{array}{l}\text { Desires to } \\
\text { have } \\
\text { children }\end{array}$ & $\begin{array}{l}\text { Intends to } \\
\text { have } \\
\text { children }\end{array}$ & $\begin{array}{c}\text { Level of } \\
\text { education (years } \\
\text { in school) }\end{array}$ & $\begin{array}{l}\text { HIV status and } \\
\text { year known }\end{array}$ & $\begin{array}{l}\text { Employment } \\
\text { status }\end{array}$ \\
\hline M & 38 & Married & 4 & No & No & No & $\begin{array}{c}\text { Primary } \\
\text { (7 yrs) }\end{array}$ & $\begin{array}{c}\text { HIV-positive } \\
2005\end{array}$ & Tailor \\
\hline \multicolumn{10}{|l|}{ C11 } \\
\hline $\mathrm{F}$ & 32 & $\begin{array}{l}\text { Widowed; in } \\
\text { a relationship }\end{array}$ & 3 & $\begin{array}{c}\text { Yes } \\
2004\end{array}$ & Yes & No & $\begin{array}{l}\text { Secondary } \\
\text { (11 yrs) }\end{array}$ & $\begin{array}{c}\text { HIV-positive } \\
1999\end{array}$ & Self- employed \\
\hline M & 39 & $\begin{array}{l}\text { Widowed; in } \\
\text { a relationship }\end{array}$ & 4 & $\begin{array}{c}\text { Yes } \\
\text { November } \\
2004 \\
\end{array}$ & Yes & No & $\begin{array}{l}\text { Secondary } \\
\quad(9 \text { yrs })\end{array}$ & $\begin{array}{l}\text { HIV-positive } \\
\text { Aug. } 2004\end{array}$ & Self- employed \\
\hline \multicolumn{10}{|l|}{$\mathrm{C} 12$} \\
\hline $\mathrm{F}$ & 36 & $\begin{array}{l}\text { Single; in a } \\
\text { relationship }\end{array}$ & 1 & $\begin{array}{c}\text { Yes } \\
\text { April } 2004\end{array}$ & Yes & Yes & $\begin{array}{l}\text { Secondary } \\
\text { (11 yrs) }\end{array}$ & $\begin{array}{l}\text { HIV-positive } \\
\text { Dec } 2002\end{array}$ & Peer counsellor \\
\hline M & 38 & $\begin{array}{l}\text { Divorced; in } \\
\text { a relationship }\end{array}$ & 3 & $\begin{array}{c}\text { Yes } \\
\text { May } 2004\end{array}$ & Yes & Yes & $\begin{array}{l}\text { Secondary } \\
\text { (11 yrs) }\end{array}$ & $\begin{array}{l}\text { HIV-positive } \\
2003\end{array}$ & $\begin{array}{c}\text { Security guard, } \\
\text { part time peer } \\
\text { counsellor }\end{array}$ \\
\hline \multicolumn{10}{|l|}{$\mathrm{C} 13$} \\
\hline $\mathrm{F}$ & 34 & Married & 3 & Yes & Yes & No & $\begin{array}{c}\text { Primary } \\
\text { (7 yrs) }\end{array}$ & $\begin{array}{l}\text { HIV-positive } \\
\text { January } 2004\end{array}$ & unemployed \\
\hline M & 30 & Married & 2 & $\begin{array}{c}\text { Yes } \\
\text { July } 2004 \\
\end{array}$ & Yes & No & $\begin{array}{c}\text { Secondary } \\
(11 \mathrm{yrs})\end{array}$ & $\begin{array}{l}\text { HIV-positive } \\
\text { October } 2003\end{array}$ & Security guard \\
\hline \multicolumn{10}{|l|}{$\mathrm{C} 14$} \\
\hline $\mathrm{F}$ & 24 & $\begin{array}{l}\text { Single; in a } \\
\text { relationship }\end{array}$ & 0 & No & Yes & No & $\begin{array}{l}\text { Secondary } \\
\text { (11 yrs) }\end{array}$ & $\begin{array}{l}\text { HIV-positive } \\
\text { January } 2004\end{array}$ & Self- employed \\
\hline M & 29 & $\begin{array}{l}\text { Single; in a } \\
\text { relationship }\end{array}$ & 0 & No & Yes & Yes & $\begin{array}{c}\text { Secondary } \\
(11 \mathrm{yrs})\end{array}$ & $\begin{array}{c}\text { HIV-positive } \\
\text { Dec. } 2003\end{array}$ & Unemployed \\
\hline \multicolumn{10}{|l|}{$\mathrm{C} 15$} \\
\hline $\mathrm{F}$ & 35 & Married & 1 & No & Yes & No & $\begin{array}{c}\text { Primary } \\
(7 \mathrm{yrs})\end{array}$ & $\begin{array}{l}\text { HIV-positive } \\
\text { Feb. } 2005\end{array}$ & Self- employed \\
\hline M & 30 & Married & 1 & No & Yes & No & $\begin{array}{c}\text { Secondary } \\
(9 \mathrm{yrs})\end{array}$ & $\begin{array}{l}\text { HIV-positive } \\
\text { March } 2005\end{array}$ & Self- employed \\
\hline
\end{tabular}

Questioned on his partners' views on the issue of having children, C7 M said, "I do not think she wants a child now, she cannot say I want a child because she knows my status, she knows her status and she knows about life".

Even among those couples who did not intend or desire to have any more children, there were cases where partners did not express or communicate their positions vis-a-vis reproduction to each other. For example, in couple 6, both partners do not want to have any more children. Both indicated that they had not discussed this with each other. They just assumed that since they used the condom consistently and the woman also had a loop, this communicated their intentions. While, in these cases, the couples had usually similar views or positions about the reproductive issues concerned, even though they had not discussed them, there were some couples where this was not the case. In some couples, their desires or intentions were incongruent. Thus though they had both made decisions at the individual level, there was still a need to communicate decisions at the couple level.

While some couples discussed all issues related to their reproductive and sexual lives, that is, $\mathrm{C} 12$ and $\mathrm{C} 2$, some couples discussed only some of the issues (C5, C1, and C3) while others did not discuss or communicate about these issues at all (C7 and C6). Thus, in some couples, there was lack of communication on important reproductive and sexual issues leading to assumptions and suppositions on the position or stand point of the other partner. Though in most cases in this study, the couple's assumptions about each other were usually correct, such a lack of communication on reproductive issues may possibly lead to conflict in relationships.

3.2. Decision Making Regarding Contraceptive Use. Most of the relationships under study were relatively new and most of the respondents met well after they knew their HIV status. They had undergone counselling and had been taught about issues of reinfection, mother to child transmission of HIV (MTCT), and general health requirements if one is HIVpositive. The importance of the condom in the reproductive lives of HIV-positive people had been impressed on the minds of many through counselling and support groups. As a result, many couples reported that insofar as condom use in their sexual lives was concerned, no conscious decision was 
made. Given their HIV status, condom use was assumed to be the logical thing to do.

Among the HIV-positive couples studied, women seemed to be able to determine the nature of their contraceptive and reproductive interaction with their partners. In couples 3,13 , and 15 (all married couples), it was the women who introduced the use of the condom in their relationships. In instances like $\mathrm{C} 14$ and $\mathrm{C} 15$, where male partners did try to protest against condom use, women stuck to the "no condom, no sex" mantra. Commenting on this Couple 14, female said,

"no, we never did it that way... when he wanted to do it without a condom I would refuse. I would tell him that if you do not want go and look for other women outside, it is your life."

On the issue of other contraceptive methods, most men felt that it was up to the woman to use any other family planning methods or not. Some men said they had discussed the issue of dual protection with their partners but the general feeling was that it was up to the woman to make up her mind whether to use dual protection or the condom alone. A number of women also pointed out that their partners did encourage them to use dual protection.

\subsection{A Description of the Reproductive Decision Making Pro-} cess. Unlike HIV-negative couples, those who are positive are usually in no position to expect pregnancies "just to happen" or to be nonchalant about being pregnant [5]. First, because of their ill health, they have to consider the impact that pregnancy may have on their health. They also have to guard against reinfection and its possible impact on their health; hence, they have to minimise unprotected sexual encounters. Unprotected sex has to coincide with the fertile period of the woman if pregnancy is the desired result. Thus being HIV-positive catapults couples into a unique and complex context in terms of reproductive decision making. To them, it becomes paramount to make rational and conscious decisions to have or not to have a child at a particular time as this has implications for their overall health and well-being.

Among the fifteen couples studied, some were confronting and others had confronted reproductive decision making, while others had done neither (nondecision makers) since knowing their HIV positive status. The focus of the discussion will be those couples and individuals who intended to have children and who had discussed their intentions as a couple. As such the discussion will centre on $\mathrm{C} 1, \mathrm{C} 5, \mathrm{C} 9, \mathrm{C} 12$, and C14. It will attempt to reconstruct the decision making process from the time one partner conceived the idea to have a child up to the time they made a choice or decision as a couple. The process of decision making in this study will be characterised as occurring in a number of stages: from when the idea is triggered to discussion between partners to searching for information, to weighing the risks and benefits of having a child and finally the decision itself. These stages by no means represent a linear progression of reasoning or action in the process of decision making. The attempt here is to describe what goes on from the time the idea of having a child is first conceived to the time a decision is made.
3.4. Triggers to Decision Making. It is not easy to determine exactly when and why the idea to have a child enters one's mind but a number of factors that trigger the idea and the need to make a decision were identified in the study. These are different from individual to individual or couple to couple but they all seem to stem from the deep-seated need to have a child or a child of a certain sex for those who already have a child or children. There are factors that act as common denominators to all individuals who intend to have a child. They include the availability of highly active antiretroviral therapy (HAART) and their confidence in it; their current health status and social comparison. The spark that sets the fire alight however seems to differ from individual to individual or couple to couple.

For C1M, C5F, and others, the fear of dying without a child after recovering from a serious illness seems to have been the trigger. Recovering from a serious sickness was a major life event that made them aware of their mortality. It acted as a powerful trigger for the concerned individuals to try and leave a legacy through their children. The availability of information on HAART, MTCT, and reproduction through counselling and other media also acted as a trigger in the decision making process. $\mathrm{C} 5 \mathrm{~F}$ pointed out that she had always wanted to have her own child and that her improved health as a result of ARVs had played a significant role in pushing her towards the idea of having a child. She said, "actually (the availability of ARVs) helped. I think that is what made me decide to have a child."

For $\mathrm{C} 12$, the triggering factor to try for a child stemmed from the need to eliminate negative family involvement in their relationship. They had decided to try for a child at a time when they were under pressure from the woman's parents to end their relationship. Her parents did not approve of her sexual relationship with a man in her current state of health. Commenting on this she said,

\section{for them "...someone with HIV should not have sex. My mother, whenever I meet her, she always says, "my child, never do it. When you have sex, you will die quicker..}

$\mathrm{C} 12 \mathrm{M}$ also concurs that the family resistance to their relationship triggered the idea of having a child as a way of securing their relationship. So the reasoning behind their attempt to have a child was that if the woman became pregnant, her parents would be forced to accept her relationship and as such leave them alone. Commenting on this, she said,

"there is a time last year in December when I
missed my period for 3 months. I was happy
because I saw it as a way of stopping my parents
from interfering in my relationship because if I
was pregnant and with a child they would give
up..."

Though there are common factors in wanting a child, what triggers the need for a decision at a particular time differs from individual to individual or couple to couple. With the idea of having a child having been conceived, how then do couples or individuals proceed in fulfilling their quest? 
3.5. Discussion and Decisions between Partners. With the idea having been triggered, the next step taken by most was to discuss it with their partners. As indicated earlier, most couples in the study said that decisions in their relationships are made through open discussion and communication with each other. C5F said that having conceived the idea, she approached her partner and informed him about her desires. They discussed the issue and considered the obstacles to it and conditions favouring their desire. In their discussion they considered their current state of health, the implications of HAART on reproduction and their financial situation. Having considered these issues they agreed to have a child in the near future but only after their health and financial situation had improved. Commenting on how they came to this decision and what issues they considered C5M said,

"...we have discussed this thing thoroughly and I have said no XXX your CD4 count; her CD4 was 44 by then while mine was 158, and I was saying with your CD4 at 44 now, at least for us to be able to have a child; it should be around eight hundred to over a thousand. So we discussed it ...until we are satisfied that our CD4 cell count is alright; we will not have a child because we have also enquired and talked to people in the field of medicine, trying to find out what the odds are; now we are quite aware of what we are supposed to do.

While C5M emphasized their health concerns, C5F focused on the financial aspect. She pointed out that she intends to have a child in the near future but "I am waiting until I am financially stable."

In their discussions, the couples raised a number of key issues and some of which are their concern about health, MTCT, the role of ARV's in reproduction, their parenting abilities, and the issue of financial resources. Health concern was the main reason that made $\mathrm{C} 1 \mathrm{~F}, \mathrm{C} 9 \mathrm{~F}$, and $\mathrm{C} 14 \mathrm{~F}$ decide not to accede to their partner's suggestions of having a child. $\mathrm{C} 1 \mathrm{~F}$ indicated that her partner did express his desire to have a child but she turned him down because of concern about her health. She said,
"ya-a, he talked about it but I do not see any way forward for now. You see this other partner will be safe but when I become pregnant, my immune system will go down you see."

The male partner however indicated that he still intends to have a child and C1F did indicate that if her health situation changed, she may consider having a child. She said, "I have the desire that maybe one child but here is HIV... in the future maybe and I will also be doing it for his sake because he has no child." Thus not having a child or not having a child together and the need to have a child of a particular sex influenced the reproductive behaviours of the respondents.

In couple 9, an HIV discordant couple, the issue of childbearing has been discussed. The male partner, who is
HIV-negative, intends to have a child. However, the female partner, despite her desire to have a child, has decided not to have one in the near future. Responding to the question of whether they had discussed the issue of having a child as a couple, she said,

\begin{abstract}
"we were talking about it in this past month; he was saying that he now wants a child. I told him that if he was serious, we should go for counselling but I know he will not do that.".
\end{abstract}

In the case of $\mathrm{C} 12$, the initial decision was to have a child immediately so as to get rid of family interference in their relationship. However having had a false hope (the woman missed her period for three months and thought that she was pregnant) and with the family pressure having subsided over time, the couple decided to delay trying for a child. They still intend to have a child soon, "maybe early next year (2011)", as indicated by $\mathrm{C} 12 \mathrm{~F}$. The consideration of their financial position was an added factor that convinced them to delay trying for a child by a year. C12F indicated that they sat down and discussed their new position and decided to firstly try to be financially stable, so that they would be able to care for their child. Narrating how they came to this new decision, she said,

"we sat down and I told him that my friend,
in the near future I would want a child but for
now because of our condition which we know, let
us first of all prepare for our child, so that if it
happens, that my health deteriorates after having
the child, you would have the resources to hire a
maid to help you take care of the child, rather than
having a child who will give us financial problems
tomorrow."

Among the couples where both or one partner intends to have a child, it seems that the decisions that were made were a result of discussions and consultations. The discussion involved the consideration of factors that the couples regarded as critical in deciding whether to have or not to have a child. These included their readiness to be parents, their financial standing, and the impact of pregnancy on their health as well as the health risks to the child. The evaluation of these factors determined the standpoint of each individual during the discussion stage.

3.6. Searching for Information. Information gathering emerged as a continuous process from the time the idea of having a child was triggered up to the decision making stage and beyond. Those who intended to have a child or children reported that they sought information about the risk involved in having a child, the effects of pregnancy on their health, the effectiveness of ARVs and nevirapine in reducing MTCT, the possible impact on ARVs on their health as well as that of the child, and also the possible delivery options. The concern about the possible negative health impact of pregnancy and the concern about the health of the child seem to have been the main factors among those who decided not to accede to their partners' desires to have a child, that is, $\mathrm{C14F}, \mathrm{C} 9 \mathrm{~F}$, 
and C1F. On the other hand, the need to have a child and the optimism on the effectiveness of HAART and nevirapine on reducing the risk of MTCT seemed to have been the main factors among those whose joint decision was to have a child in the near future, that is, C5 and C12. The couples and individuals who intend to have children indicated that they gathered or searched for information mainly from the print and electronic media, the pamphlets from health and opportunistic infections clinics, counselling sessions, support groups, and health professionals. C5, C12, and C1M all said they had direct discussion with health professionals on the issue of having children. They pointed out that they got worthwhile information from these discussions though most did indicate that the information they got was neither balanced nor unprejudiced.

The sample results indicate that men were more proactive in searching for information. This may be because in the cases of, $\mathrm{Cl}, \mathrm{C}$, and $\mathrm{C} 14$, the male partners did not have any surviving children while the women already had children. Thus men may be motivated by their burning desire to have a child who will carry on their name once they die. It is important to note that when the reproductive decisions/choices were made, they were based on the information available to the couple at that particular time and on their understanding of HIV and reproductive issues at that time. Since the situation in the frontline against HIV is continuously evolving, the men may have felt that by continuously searching for more relevant and up to date information and learning more about HIV, they may in the future be able to convince their partners to accede to their intentions of having children. It is notable that the women who did not accede to their partners' need to have a child indicated that they may change their minds in future depending on developments in the field of HIV/AIDS treatment. It seems to these couples that decision making is not conceived as static but rather as a process in motion which responds to changing contexts.

3.7. Risk-Benefit Analysis. The process of reproductive decision making also entails the risk-benefit analysis of having a child, hence the justification by couples/individuals of why they decided for or against having a child. To the two couples (C5 and C12) who decided to have a child in the near future, the benefit of having a child outweighed the risks involved. To the women who refused to have a child, the risks posed by having a child were perceived as outweighing the joy of having a child. Among the couples who considered the issue of having children, it seems that their decision involved the assessment of the following factors: their own psychosocial and economic readiness to have a child, the risk estimation to their health, and the risk estimation of MTCT. In the cases of $\mathrm{Cl}, \mathrm{C}$, and $\mathrm{C} 14$ while the men were psychologically ready to try for a child the women, as it seems, were not. The women also felt that the risk to their health was high and they were not willing to take any chances with the risk of vertical transmission as they were not ready to take care of an HIVpositive child.

The possibility of perinatal transmission of HIV was a critical concern for the women in determining whether to have or not to have a child. C14F pointed out that she was afraid "to have a positive child" and that she was also concerned about her health. She said, "...I am also concerned about my health you see. It is said that if you give birth, your health deteriorates and so on. That is what I do not want. I still want to live." Similar sentiments were expressed by CIF and $\mathrm{C} 9 \mathrm{~F}$ which may point to the fact that they are not yet psychologically ready to have a child unlike $\mathrm{C} 12 \mathrm{~F}$ and $\mathrm{C} 5 \mathrm{~F}$ whose outlook on having a child is generally positive. The couple's psychosocial readiness to have a child involved a number of considerations including their satisfaction with the number of children living with them, the stability of their health, and their financial standing. C5 and $\mathrm{C} 12$ decided to delay having a child because of the consideration of some of these issues. They wanted to be in a better state of health (C5) as well as being financially stable (C5 and C12) in order to be able to discharge their parental duties effectively.

\section{Discussion}

The decision making process among HIV-positive couples revealed that decision making is not straightforward as people do not always have similar desires or methods with which to attain those desires. The decisions made by these couples were a result of negotiation and compromise. Although there were differences of opinion and disagreements, the couples indicated that they were able to make collaborative decisions.

Even though couples indicated that decisions reached were collaborative, there tended to be a dominant partner in the decision making process. The fertility and sexual preferences of women tended to determine the couple's decisions on reproduction and contraception. In couples where the men intended to have a child now or in the near future and the woman did not want to have a child (for example $\mathrm{Cl}$ and $\mathrm{C} 14$ ), the usual outcome was that the couple decided not to have child. The fact that most of the time the preferences of the female were the ones that were implemented indicates that to a larger extent, the females dominated the process. Women exercised considerable power and influence in decision making among HIV-positive couples.

Most studies in the area of gender, power, and decision making concur that in patriarchal societies, it is the norm for the husband or the man to determine or dominate decisions regarding child bearing [6-8]. It is regarded as conventional wisdom that men dominate reproductive decision making [9-11]. Among the study sample, however, gender relations of power seem to have shifted regarding the issue of reproductive decision making, that is if conventional wisdom on this issue is accepted as the norm. Among the HIV-positive couples, it was not the norm for men to exercise the ultimate voice in reproductive decisions.

Some of the findings of this study are in tandem with the findings of a study by Maharaj and Cleland (2005) [12]. In their study in KwaZulu-Natal, they found that contrary to generally held views, among the Zulu, the wife's own desire to avoid future child bearing was the strongest predictor of contraceptive use. Thus instead of the husband, it was the wife who had greater influence on deciding whether to use or not 
to use contraception. This is usually helped by the fact that among both the Zulu and the Ndebele, the woman is usually regarded as responsible for contraception [13]. As Maharaj and Cleland [12] note, among couples where the female is perceived as having responsibility over contraception, the woman is more likely to control decision making regarding the method of contraception. Traditionally, women have always been perceived as having responsibility over contraception and child spacing among the Ndebele and this seems to be still the fact among the HIV-positive couples studied [13]. The fact that women seem to dominate contraceptive decision making among the study sample should therefore be seen as the norm rather than the exception.

A study on "fertility and child death in Zimbabwe" carried out in 1999 in both urban and rural settings [5] found that a considerable number of women regarded it as the norm for men to determine when to have another child. The main reason given for this was that men were the main bread winners and were therefore accorded more power within the household. This observed dominance of men in reproductive decision making went largely unchallenged because most respondents regarded it as part of the societal and marital norms [5]. Given the characterisation of women's lack of voice in relationships in the literature $[5,10,14-16]$, one would not expect the high visibility of HIV-positive women in reproductive decision making.

This observed decision making pattern between men and women under study may be partly explained from the behavioural change perspective. It can be argued that the assertiveness and the greater assessment of risk shown by some HIV-positive women are an effect of their state of health. Their state of health demands that they modify their behaviour and actions if they are to survive. They perceive pregnancy as a risk to their health that can only be avoided by making their voices heard in the decision making process. Taking a proactive stance in decision making is seen as a risk reducing measure whose benefits outweigh potential negative impacts [17-19]. As such women's voices become more prominent among HIV-positive couples because they feel it is their life that will be threatened if their sexual partners fail to understand their sexual or reproductive concerns.

Studies have shown that socioeconomic factors have an impact on the decision making process [10, 20-22]. The level of education as well as the income generation power or occupation of both male and female is factors that can play a significant role in the process of decision making $[7,23]$. The study results however indicated that the level of education of the respondents did not have a differential impact on the reproductive decisions of the couples studied. It was found that irrespective of educational level, women's reproductive and contraceptive intentions tended to prevail. However, this seemingly nondifferential impact of formal education may have been a result of sexual and reproductive education given to couples at the opportunistic infections clinics and in support groups. This sexual and reproductive education and information may have served as a leveller in the decision making arena.
Women in the study were more risk averse than men as a result of fear of reinfection and mother to child transmission of HIV. The understanding of possible health impacts of pregnancy and reinfection as well as the psychosocial impact of having an HIV-positive child seemed to influence the reaction and action of women regarding child bearing and contraception. This risk-averse behaviour taken by most women in the study was based on the information that they had at the time of decision making. Most women in the study had exposure and access to HIV and reproductive health related information mainly through the opportunistic infections clinics and support groups. And it seems regardless of educational level or economic-social status they all used this information to strengthen their bargaining power in decision making. This informational empowerment of both men and women may have helped women in this study to be more verbally assertive in sexual and reproductive communication in order to protect themselves, their partners, and possible offspring.

While couples in this study described their decisions as collaborative, their accounts of the decision making process tended to indicate that it was not the case that partners were equally involved in every step of the decision making process. The partner who came up with the idea of having a child was usually the most active in research and information gathering [24]. They usually also took a lead in the decision making process in that they were the ones who introduced and led the discussion. This however did not mean that it was their views or intentions that prevailed when the final decision was made as the other partner had the power to veto the decision [24-26]

Among the study sample, only six women and one man were unemployed. All of other respondents were either in formal or informal employment. Most women in the study sample, as it can be argued, were economically selfsufficient. From this, it can be further argued that their high visibility in reproductive and contraceptive decision making stems from this self-sufficiency and non-dependence on men. This is in line with most studies that argue that as women become more economically independent, their involvement and impact on decision making become more significant $[10,24,27,28]$. The difficulty with this argument though is that even in cases where women were unemployed and their partners were the sole breadwinners, the women's reproductive and contraceptive preferences still dominated the decision outcomes. Thus economic independence did not seem to have a differential impact in reproductive decision making among the HIV-positive couples.

\section{Limitations of the Study}

This study utilised the snowball method in recruiting some of the study respondents. The main problem with this method, however, was the production of a somewhat homogeneous and atypical sample which was not representative of all HIVpositive couples in Bulawayo. This was because referrals were dependent on the social networks of the respondents first accessed. Due to the selection bias which produced 
a particular group of respondents with close interrelationships, the results of this study are not generalizable to all HIVpositive couples.

\section{Conclusion}

Decision making can be characterised as occurring in a number of stages. Usually one partner raised the issue for discussion in response to a specific trigger. There was initial discussion followed by research and information gathering on the issue. The couples discussed options available to them based on the information they had. They weighed the risks and benefits of these options before finally making a "collaborative" decision. Usually one partner was more proactive than the other in the decision making process but since both were involved in the final discussion, they felt that they contributed to the final decision collaboratively.

Among HIV-positive couples studied, men do not dominate reproductive and sexual decisions. In fact in the majority of cases women seem to be the ones who exercise more power. The study found that the reproductive and contraceptive needs and intentions of women usually determined whether a couple would try for a child or not and whether they would use contraception and which one. The male partners' fertility desires usually did not have a significant influence on the ultimate decision taken by the couple. Among HIV-positive couples studied, women were neither powerless nor voiceless.

Considering the importance accorded to reproductive health information by couples in this study, it is important to avail unprejudiced and up to date information to these couples. There were notable knowledge gaps among the study sample regarding the impact of pregnancy on HIV/AIDS progression when one is on HAART as well as on the impact of HAART in mitigating MTCT. More information on the impact of pregnancy on the health of the mother, the impact of prophylactic drugs on the foetus, the relationship of HAART, MTCT, high CD4 cell count and pregnancy, and other health and psychosocial issues related to pregnancy and childbearing needs to be made readily available and accessible to HIV-positive people.

These study results are significant in the current debate on gender power dynamics in decision making. However, it is important to note that they are from a small urban study and hence generalisations cannot be drawn from them.

\section{Conflict of Interests}

The authors declare that there is no conflict of interests regarding the publication of this paper.

\section{References}

[1] UNAIDS, “Global AIDS Response Progress Report," 2012, Zimbabwe, http://www.unaids.org/en/dataanalysis/knowyourresponse/countryprogressreports/2012countries/ce_ZW_Narrative_Report.pdf.

[2] T. Mutasa-Apollo, "Scaling Up Treatment in Zimbabwe: The path to high coverage," 2013, http://apps.who.int/hiv/events/ 2013/2_apollo_scaling_up_zim_ias_v_3_2.pdf.
[3] W. L. Neuman, Social Research Methods: Qualitative and Quantitative Approaches, Allyn \& Bacon, Oxford, UK, 2008.

[4] L. G. Johnston, K. Sabin, M. T. Hien, and P. T. Huong, "Assessment of respondent driven sampling for recruiting female sex workers in two Vietnamese cities: reaching the unseen sex worker," Journal of Urban Health, vol. 83, no. 1, pp. 16-28, 2006.

[5] M. Grieser, J. Gittelsohn, A. V. Shankar et al., "Reproductive decision making and the HIV/AIDS epidemic in Zimbabwe," Journal of Southern African Studies, vol. 27, no. 2, pp. 225-243, 2001.

[6] M. Chapagain, "Conjugal power relations and couples' participation in reproductive health decision making: exploring the links in Nepal," Gender, Technology and Development, vol. 10, no. 2, pp. 159-189, 2006.

[7] I. S. Speizer, L. Whittle, and M. Carter, "Gender relations and reproductive decision making in Honduras," International Family Planning Perspectives, vol. 31, no. 3, pp. 131-139, 2005.

[8] M. E. Greene and A. E. Biddlecom, "Absent and problematic men: demographic accounts of male reproductive roles," Population and Development Review, vol. 26, no. 1, pp. 81-115, 2000.

[9] L. Duffy, "Culture and context of HIV prevention in rural Zimbabwe: the influence of gender inequality," Journal of Transcultural Nursing, vol. 16, no. 1, pp. 23-31, 2005.

[10] R. Feldman and C. Maposhere, "Safer sex and reproductive choice: findings from "positive women: voices and choices" in Zimbabwe," Reproductive Health Matters, vol. 11, no. 22, pp. 162173, 2003.

[11] G. Sen and P. Ostlin, "Unequal, Unfair, Ineffective and Inefficient. Gender Inequity in Health: why it exists and how we can change it," 2007, http://www.who.int/social_determinants/resources/csdh_media/wgekn_final_report_07.pdf.

[12] P. Maharaj and J. Cleland, "Women on top: the relative influence of wives and husbands on contraceptive use in KwaZulu-Natal," Women \& Health, vol. 41, no. 2, pp. 31-41, 2005.

[13] P. Nyathi, Traditional Ceremonies of AmaNdebele, Mambo Press, Gweru, Zimbabwe, 2001.

[14] C. Baylies and J. Bujra, "Discourses of power and empowerment in the fight against HIV/AIDS in Africa," in AIDS: Safety, Sexuality and Risk, P. Aggleton, P. Davies, and G. Hart, Eds., Francis \& Taylor, London, UK, 1995.

[15] T. Wilton, EnGendering AIDS, SAGE, London, UK, 1997.

[16] M. Machera, "Opening a can of worms: a debate on female sexuality in the lecture theatre," in Rethinking Sexualities in Africa, S. Arnfred, Ed., Almqvist \& Wiksell, Uppsala, Sweden, 2004.

[17] C. A. Rietmeijer, "Resurgence of risk behaviors among men who have sex with men: the case for HAART realism," Sexually Transmitted Diseases, vol. 32, no. 3, pp. 176-177, 2005.

[18] K. Prager, "Understanding Behaviour Change," 2012, http:// www.environment.scotland.gov.uk/pdf/Understanding_Behaviour_Change.pdf.

[19] J. Morris, M. Marzano, N. Dandy, and L. O’Brien, “Theories and models of behaviour and behaviour change," 2012, http://www.forestry.gov.uk/pdf/behaviour_review_theory.pdf/\$ file/behaviour_review_theory.pdf.

[20] B. T. Huong, “'Let's talk about sex, baby': sexual communication in marriage in contemporary Vietnam," Culture, Health \& Sexuality, vol. 12, supplement 1, pp. S19-S29, 2010.

[21] M. Beres, "Sexual miscommunication? Untangling assumptions about sexual communication between casual sex partners," Culture, Health \& Sexuality, vol. 12, no. 1, pp. 1-14, 2010. 
[22] S. B. Kirshenbaum, A. E. Hirky, J. Correale et al., “'Throwing the dice': pregnancy decision-making among HIV-positive women in four U.S. cities," Perspectives on Sexual and Reproductive Health, vol. 36, no. 3, pp. 106-113, 2004.

[23] M. R. Dudgeon and M. C. Inhorn, "Men's influences on women's reproductive health: medical anthropological perspectives," Social Science \& Medicine, vol. 59, no. 7, pp. 1379-1395, 2004.

[24] A. Wood, K. Downer, B. Lees, and A. Toberman, "Household financial decision making: qualitative research with couples," 2012, http://research.dwp.gov.uk/asd/asd5/rrs-index.asp.

[25] C. J. Dommering, M. R. van den Heuvel, A. C. Moll, S. M. Imhof, H. Meijers-Heijboer, and L. Henneman, "Reproductive decision-making: a qualitative study among couples at increased risk of having a child with retinoblastoma," Clinical Genetics, vol. 78, no. 4, pp. 334-341, 2010.

[26] B. Wolff, A. K. Blanc, and J. Ssekamatte-Ssebuliba, "The role of couple negotiation in unmet need for contraception and the decision to stop childbearing in Uganda," Studies in Family Planning, vol. 31, no. 2, pp. 124-137, 2000.

[27] J. Gaventa, "Participation and Citizenship: Exploring Power for Change," 2007, http://www.odi.org.uk/sites/odi.org.uk/files/ odi-assets/events-presentations/121.pdf.

[28] X. Xu and S.-C. Lai, "Resources, gender ideologies, and marital power: the case of Taiwan," Journal of Family Issues, vol. 23, no. 2, pp. 209-245, 2002. 


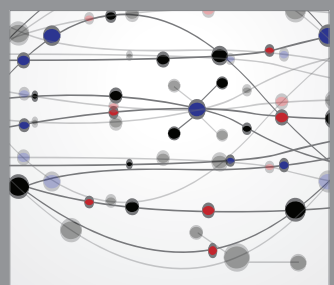

The Scientific World Journal
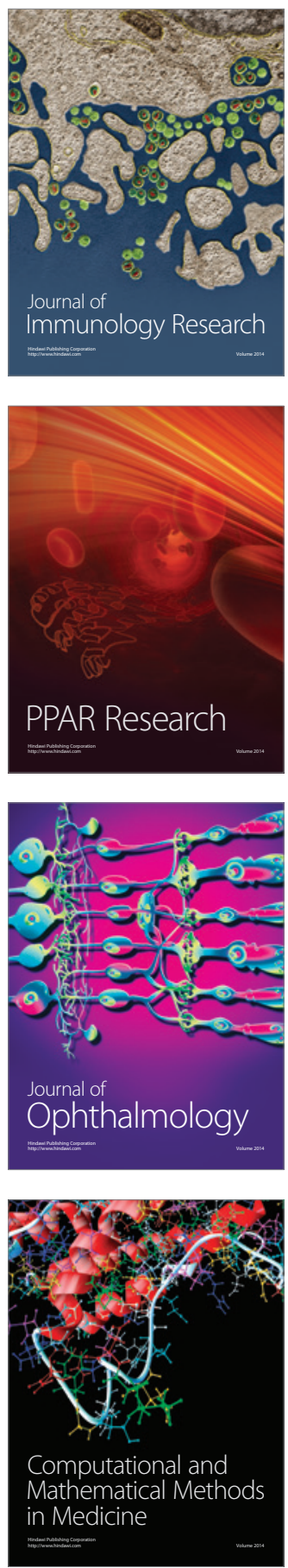

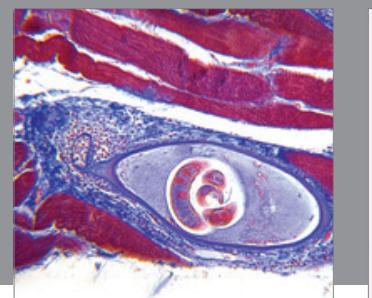

Gastroenterology

Research and Practice
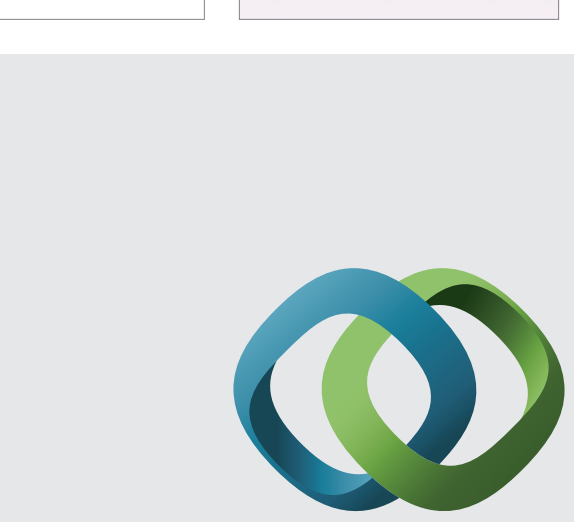

\section{Hindawi}

Submit your manuscripts at

http://www.hindawi.com
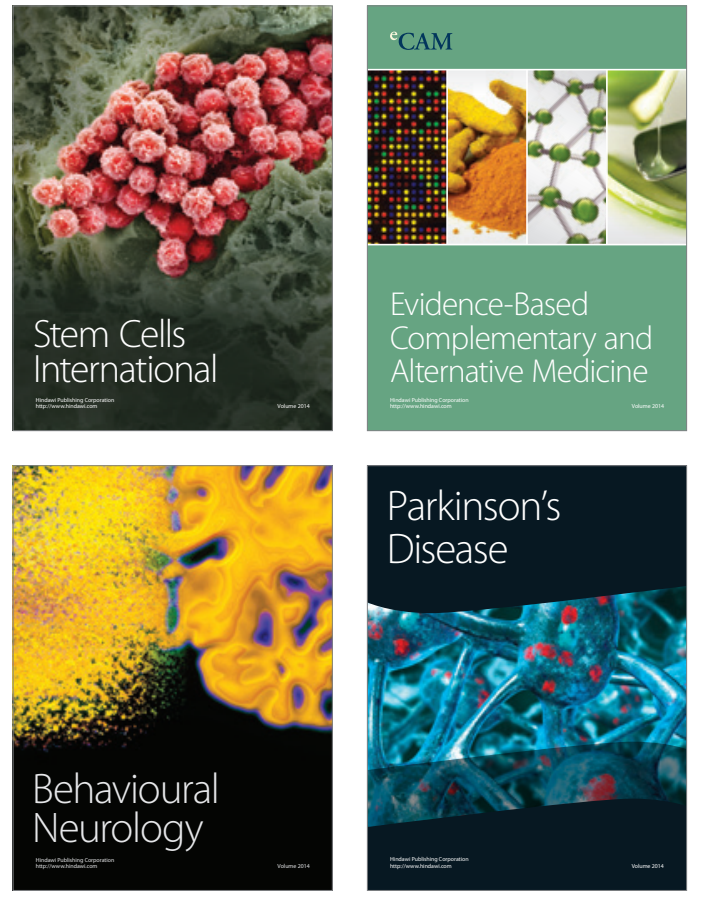
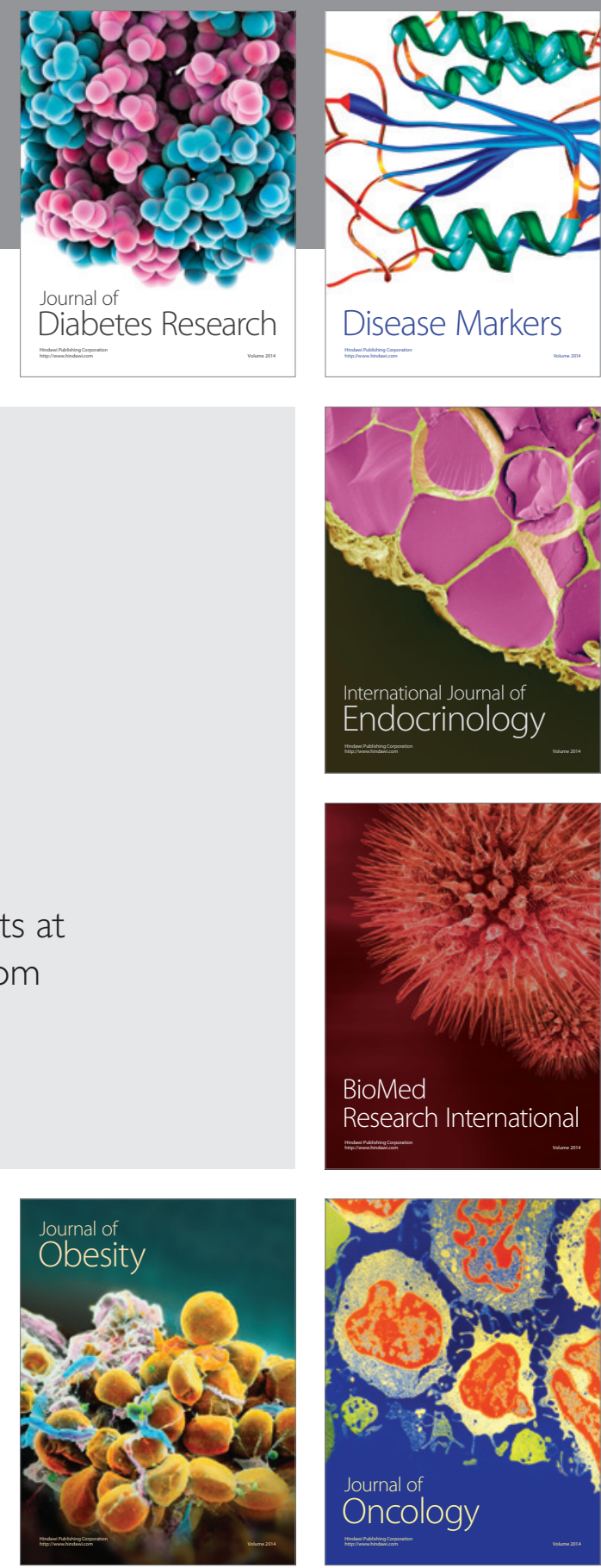

Disease Markers
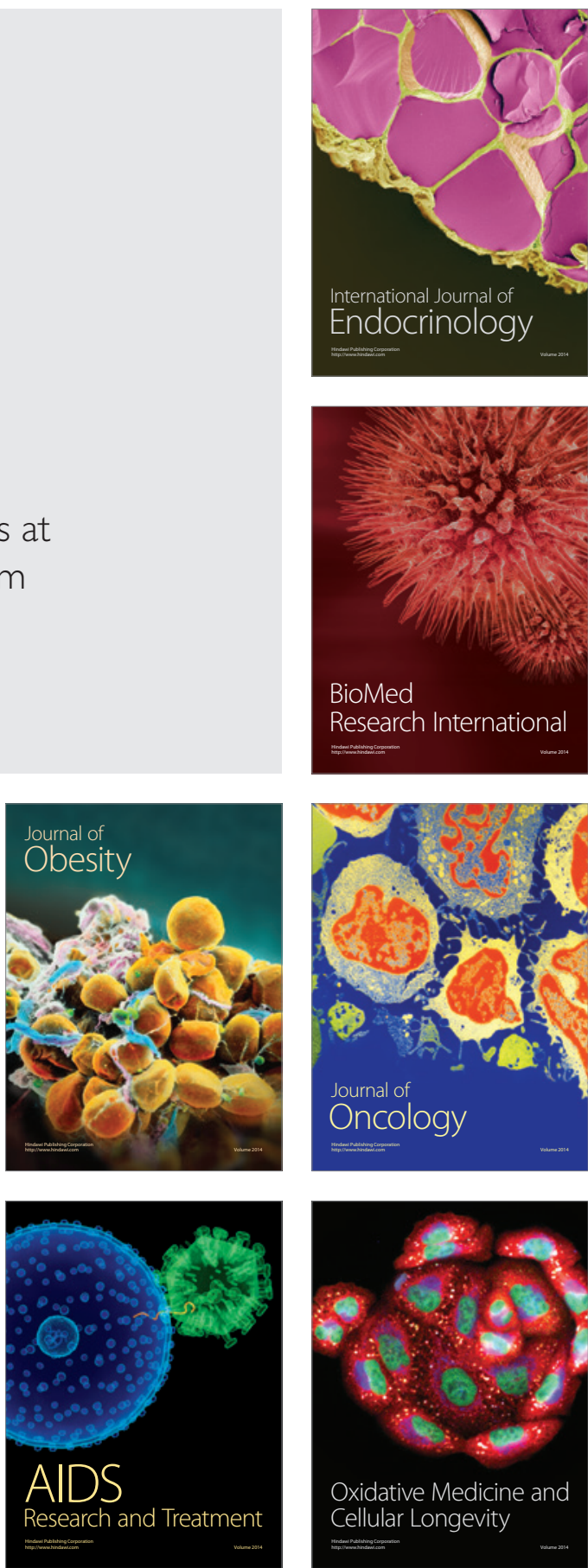